Mendes, LF., de Souza, J., Buhalis, D., 2019, Evaluating the effectiveness of tourist promotions to improve the competitiveness of destinations, Tourism Economics, , https://doi.org/10.1177/1354816619846748

\title{
Evaluating the effectiveness of tourist advertising to improve the competitiveness of destinations
}

\begin{abstract}
The present study focused on evaluating the effectiveness of tourist destination advertising. The Destination Advertising Response (DAR) Model was used to analyze data on the effectiveness of destination promotional campaigns on visitor expenditures in six trip facets: destination, accommodations, attractions, restaurants, events, and shopping. Independent sample $t$-tests were conducted to identify any differences in total destination spending among the groups of those visitors influenced for each trip facet. A multiple regression analysis was performed to discriminate the performance of the travel facets expenditures in the estimation of total expenditures. Significant results indicate that the 'Destination', 'Accommodations' and 'Restaurants' facets directly influence the total expenditures. The self-planners had the highest variance explaining in total visitor expenditure compared to the regression analysis results of the other two groups (i.e., travel agencies and online travel agencies). The study also explores how destinations can improve their competitiveness on tourist advertising by using technologies.
\end{abstract}

\section{Keywords}

destinations, advertising, competitiveness, DAR model, technologies 


\section{Introduction}

Evaluating the effectiveness of advertising on sales goes back to the 1930s (Butterfield et al., 1998). The importance of conducting studies for this purpose occurs because organizations need to examine whether promotional expenditure achieves return on investment. To verify the effectiveness of tourist destination advertising, Destination Management Organizations (DMOs) should consider the expenditure at the destination itself and on accommodation expenses, shopping, meals, attractions, etc. (Stienmetz et al., 2015). Measuring the average spending of tourists in a destination verifies if the promotional efforts are being effective or should be increased.

A series of models have been proposed over the years to measure the effectiveness of promotional campaigns for tourist destinations, namely conversion analysis, tracking analysis and econometric analysis (Butterfield et al., 1998; Kim et al., 2005; Pratt et al., 2010). Park, Nicolau and Fesenmaier (2013) have come up with a Destination Advertising Response (DAR) Model for measuring the effectiveness of facet-based destination promotional campaigns. Stienmetz et al. (2015) proposed a re-adaptation of the DAR model, providing a more solid basis for its use. Unlike the models of conversion analysis, advertising tracking, and econometric models, the DAR Model measures the effectiveness of tourism advertising based on six facets of travel (destination, accommodations, attractions, restaurants, events and shopping), not just about the destination.

This research applies the DAR model to analyze the effectiveness of destination promotional campaigns on visitor expenditures on these six trip facets. The model is examined using survey data from 384 travelers from all regions of Brazil. Independent sample $t$-tests are conducted to identify any differences in total destination spending among the groups of those visitors influenced for each trip facet. A multiple regression analysis is also performed to discriminate the performance of the travel facets expenditures in the estimation of total expenditures. This study extends previous work on measuring the effectiveness of tourism advertising (Park et al., 2013; Stienmetz et al., 2015) by identifying three types of groups of visitors regarding to the effectiveness of tourist destination promotions: those who were intermediated by traditional agencies; those who were intermediated by online travel agencies; and those who planned and purchased the facets of the travel on their own (i.e., self-planners).

The study also explores how destinations can improve their competitiveness on tourist advertising by using new technologies. Technologies may help tourists to visit attractions and destinations since this is a complex process influenced by multiple factors (Volchek et al., 2018). The use of technologies for the creation of brands for destinations is a relevant aspect for improving the effectiveness of tourist destination advertising. For example, travelers are shifting from passive consumers to drivers of productions (Shoval and Birenboim, 2018). Visitors use other sources of information (rather than traditional agencies and online travel agencies), such online travel reviews, available on TripAdvisor to plan their trips by themselves. Destination marketing has then changed from passive to active promotion with the diffusion of the Internet, from one-way to interactive marketing, and from collateral material to user generated content (Mistilis et al., 2014). With the significant influence of technology, social media and empowered consumers (Mendes-Filho et al., 2018), advertising managers should use digital marketing as an integral part of the tourism organization's decision-making framework (Qi et al., 2018). 


\section{Literature Review}

\section{Conversion Studies}

Conversion studies analyze individuals' responses to promotional campaigns in terms of awareness of destination, visitation, and visitor spending (Stienmetz et al., 2015). Figure 1 shows the sequential process of conversion for the advertising of tourist destinations (Siegel and Ziff-Levine, 1990). Destination advertising addresses a target audience, and this comes of the advertising and the destination. This awareness then leads the person to develop a positive image and make an inquiry (search for information). Following these steps consumers build the motivation as a result of the advertisement and finally visit the destination.

\section{----- Insert Figure 1 here -----}

Conversion studies are conducted using questionnaires to see if the target marketing recipients (potential visitors convert into actual visitors (Cai, 1998; Wicks and Schuett, 1991). For example, McLemore and Mitchell (2001) and Stergiou and Airey (2003) measured the conversion of the websites of Arkansas (USA) and Bournemouth (UK) respectively by sending online questionnaires to potential respondents who visit the official websites of the destinations. Questionnaires were sent to people who request some information about the destination. The objective of the conversion analysis is to verify if the promotion was effective for those people. However, people who do not visit the tourist destination, even though they are impacted by its promotion, are hardly attracted to answer a questionnaire. This fact is an important limitation of such studies, since most of data collections only 50 to $60 \%$ of the questionnaires are returned (Park and Fesenmaier, 2012).

Another issue of the conversion studies is that although individuals are influenced by the promotion to visit a tourist place, there are also other factors that can motivate a person to visit a destination, such as realizing a childhood wish, visiting family, participating in business meetings, among others (McWilliams and Crompton, 1997; Park et al., 2013; Stienmetz et al., 2015). Conversion studies fail to measure visitor spending, since they only focus on the choice of the destination. Visitors can make expenses on lodging, attractions, meals, among others, and the impact of advertising may be different for each of these items.

\section{Tracking Studies}

Tracking studies identify the cognitive and behavioral aspects that the advertising message generates in the individual (McWilliams and Crompton, 1997). They assume that potential visitors can be 'converted' into actual visitors from sensitization and imagebuilding. Pratt et al. (2010) reinforced this by emphasizing that such studies are conducted with consumers to provide information about their reactions at different stages of the destination's marketing process; not just the final impact of the marketing activity. These models are effective in understanding that marketing activities are capable of constructing an image about the destination, recognizing that not all activities perform the selling function.

Figure 2 illustrates the sequential process that encompasses tracking studies. Advertising causes potential visitors to become aware of destinations, and then lead them 
create a positive image about a destination. The awareness and construction of the destination image motivates individuals to ascertain information become an actual visitor, or even to perform the conversion without even the process of inquiry - just the persuasive feature of advertising.

\section{----- Insert Figure 2 here -----}

The strong similarity between the conceptual tracking and conversion models is that they follow the same hierarchical process of advertising execution and their absorption is perceived by the potential visitor of a tourist destination. The main difference with the conversion analysis is that in the screening analysis the information request is seen as optional. The conversion analysis, the information request is necessary condition for the final behavior.

Not all surveys carried out through the tracking analysis use estimates of visitors' expenses in the destination, since on the awareness of the destination image focuses this approach. For example, Klenosky and Gitelson (1997) sought to identify the different perceptions about some USA destinations from the recollection of advertising campaigns slogans. They elaborated questions that referred to the memory and perception of participants, such as: 'Of all the tourism slogans of the states that you have seen, read or heard, which one do you consider the best?'. Kim et al. (2005) performed a new tracking analysis to verify the effectiveness of advertising campaigns undertaken by Illinois. They considered important concepts of advertising, such as the 'Top of Mind', to verify the possible effects of state tourist advertising, as well as the effectiveness of certain channels of communication.

The main issue of tracking studies is the same that conversion analyses; focusing only in the destination. More recent studies consider other aspects that can be influential in the choice of the destination (Park et al., 2013; Stienmetz et al., 2015). The promotional actions of such items can stand out even more in the mind of the consumer than the campaigns of divulging their own destination.

\section{Econometric Analysis}

The econometric analysis is another approach used to measure the effectiveness of advertising campaigns for destinations, especially with regard to international visits (Butterfield et al., 1998; Uysal and Crompton, 1984). An important aspect of studies involving econometric analysis is that they are carried out during a long period of time. For example, a study with foreign visitors and their expenses in Turkey was executed during the period 1960 to 1980 (Uysal and Crompton, 1984). To perform such surveys a range of data is necessary, for instance: visitor income, exchange rates, cost of living of visitors at the destination, and expenses incurred in promotion. Promotional expenses act as a 'key variable' that is divided by visitor spending, and the results for each visitor will be that DMO invested ' $x$ ' value in promotion and customer acquisition.

Econometric models are not designed for measuring the effectiveness of tourism promotional campaigns. These are statistical analysis tools that already exist in several surveys. Researchers incorporated additional variables, in order to carry out measurements. One of the reasons why these models are not frequently used in this type of research (in comparison to the models of tracking and conversion studies), is because variables for such measurements are not incorporated in empirical research (Butterfield et al., 1998). 
Butterfield et al. (1998) created a structure to estimate the impact of tourist advertising on visitor spending, between 1987 and 1988, with the Ontario Incredible advertising campaign. The authors sought to improve the way of studying the effectiveness of destination advertising campaigns by econometric analysis. They incorporated variables that capture behavioral aspects of visitors, especially related to the decision-making process. However, they pointed out a series of deficiencies found in its implementation, along with data that would be necessary to strengthen the estimates. For example, the need of a larger sample size, follow-up over several successive years with independent samples, in addition to visitor spending to allow better predictions of expenses. More questions are also needed to characterize the behavioral processes of visitors, e.g., the number of trips carried out in the year prior to the survey.

Thus, the econometric analysis has the same issues found in both conversion and tracking studies. The destination visitation is the only factor to be weighed for the return of the promotional investments.

\section{Destination Advertising Response (DAR) Model}

The Destination Advertising Response (DAR) Model was created by Park et al. (2013) to provide the DMOs with greater depth in the effectiveness of promotional campaigns of tourist destinations disclosed to potential markets. Unlike the models of conversion analysis, advertising tracking and econometric models, the DAR Model measures the effectiveness of tourism advertising based on six facets of travel, i.e., destination, accommodations, attractions, restaurants, events, and shopping. Although visitors have never seen a destination advertisement, they may have seen promotional campaigns about the hotel where they stayed, or about the event in which they attended. These can have influenced their travel to destinations and even the acquisition of other travel facets.

Stienmetz et al. (2015) proposed an adaptation of the DAR model (Figure 3), where decisions can be identified on each of the six facets of travel and their contribution to the total expenditure on the destination. The first two stages of the DAR Model follow the same characteristics of the sequential process of conversion and tracking studies. The visitor is first exposed to the information with which an attitude is generated in this regard. Subsequently, the attitude toward advertising influence attitude toward destination.

\section{----- Insert Figure 3 here -----}

The DAR model has as parameters the analysis techniques previously proposed, until the third stage, where the acquisitions of the so-called travel facets are analyzed. Such facets are incorporated into the model by widespread theories regarding the process of travel planning. Stienmetz et al. (2015) use them to designate the six facets that can be measured from the perception of the visitor in relation to the visualization of promotional campaigns. This helps the estimation of expenses incurred with such items, included the final stage of the model.

Choe et al. (2017) did a comparison between the DAR Model with the conversion, tracking, and econometric analysis. They aimed to identify which of the techniques brought more precision in the measurement of the tourist advertising influence to the trip planning and expenses incurred in the destination. The DAR Model is the only facet-based model and it is characterized as a 'family of models', encompassing the main characteristics of the previous ones. 
However, the DAR Model has limitations. Even if there are facets of travel, the model does not consider that in trip planning there is a hierarchical process of choice (Park and Nicolau, 2015). For example, it is important to mention the planning time for the purchase of each facet, as well as the media that influenced the choice of each one. This is a complex type of research because the data collection is performed by individuals who often do not know the real meaning of advertising, or do not have the memory capacity to measure the planning time of a trip.

\section{Methodology}

This study aimed to evaluate the effectiveness of tourist advertising and how the technologies can be used to improve the competitiveness of destinations. Based on the DAR Model proposed by Stienmetz et al. (2015), four questions guided the investigation: To what degree are travel decisions (i.e., destination, attractions, restaurants, accommodations, events, and shopping) influenced by destination advertising? To what degree is the destination advertising responsible for the travel decisions that affect the amount of money spent during the visit to the destination? Can tourist groups with different sensitivities to destination advertising be identified? What technologies can be used to improve the tourist advertising effectiveness and competitiveness of destinations?

The impact of any specific destination advertising campaign was not analyzed, but rather the general communication undertaken by Brazilian destinations. Brazil and its developing tourism industry provide an interesting case for analyzing advertising effectiveness. Brazil got a record growth in 2016 with 6.6 million international tourists, and an injection of US\$ 6.2 billion in revenue in the country's economy (Agência Brasil, 2017; Ministério do Turismo, 2016).

Survey questions were sourced from validated instruments (Stienmetz et al., 2015) and modified for this study. It was necessary to add more questions to the questionnaire, mainly due to some limitations found in its adaptation to the Brazilian context. The draft survey was then evaluated by four academics and the revised survey was pretested with 32 tourists who had been influenced by Brazilian advertising campaigns. Their feedback was used to refine the layout and wording, and to further clarify the content prior to the main data collection.

In the survey carried out by Stienmetz et al. (2015), the questionnaires were sent by e-mail to respondents. These emails were obtained by travel agencies. The questionnaire was then answered by tourists who had been impacted by any advertising campaign, regardless of whether or not they went to a destination. This fact led to a limitation to carry out a similar survey procedure in Brazil. Although this type of survey is very common in the United States, this is quite complex in Brazil because the Brazilian travel agencies are resistant in providing clients' database to researchers. Another issue is that sending a complex questionnaire by email to Brazilian travelers would result in very low return of replies.

Self-administered paper-based surveys were distributed to travelers who visited Sergipe between $4^{\text {th }}$ July and $26^{\text {th }}$ November of 2016. Visitors leaving the destination after their holidays were approached to answer the survey to measure their trip expenditures in the destination. Of the 527 surveys distributed, 384 surveys (73\%) were returned. Travelers were invited to complete the survey in Sergipe airport. The state of Sergipe in the Brazilian 
Northeast region has been boosting its tourist flow in recent years from investments in infrastructure and advertising (Sergipe, 2015).

The questionnaire was composed of 46 questions, which dealt with sociodemographic aspects, characteristics of the trip planning to the destination, and visitor expenditures in six trip facets: destination, accommodations, attractions, restaurants, events, and shopping. Variables used in the questionnaire are based on the DAR model (Stienmetz et al., 2015) to evaluate the effectiveness of tourist destination advertising, i.e., gender, age, household income, trip type, trip length, trip planning time, and the number of previous visits type made to the destination. Advertising exposure was measured with four types of channels: TV/radio, magazine/newspaper, Internet, other. Tourists expenditure was measured using nominal spending categories. They were then 'transformed' into a discrete variable for visitor expenditure by taking the midpoint value for each spending category, as suggested by Park et al. (2013) and Stienmetz et al. (2015). This study added a question in order to identify whether the respondent got any trip advice from travel agencies: 'Did you have any agency to help you plan the trip? a) Yes, a traditional agency; b) Yes, an online travel agency; c) No, I made on my own.'

Respondent attitude toward the advertisements was measured using seven items (i.e., Attractive, Features, Trust, Help, Place, Knowledge, and Plan). Response options for each aspect of the advertising was assessed using a 5-point Likert scales ranging from "(1) Strongly Disagree" to "(5) Strongly Agree". The reliability of the advertisement attitude scale was calculated using the seven items. The Cronbach's coefficient alpha was 0.957, which indicates a sufficient degree of reliability (Straub et al., 2004). Descriptive statistics for advertisement attitude seven items are in Table 1. It shows that the various destination advertising materials were considered moderately attractive and with interesting features of the destination. This corroborates Stienmetz et al.'s (2015) research. However, plan was not rated as high as the others. There was substantial variability in attitudes toward the advertising as showed by the relatively high standard deviations, and the relatively high correlations among the seven items.

\section{----- Insert Table 1 here -----}

Two different types of questions were used to measure the advertising response depending on the trip facet. For example, for destination choice tourists were asked how likely they were to visit the destination even if they had not seen the advertising using a dichotomous (0/1) variable. Those responding, 'definitely yes' or 'probably yes' were given values of 1 , and those responding, 'maybe no', 'definitely no' or 'not sure' were given values of 0 . For the other five trip decisions (i.e., attractions, restaurants, events, shopping, and accommodations), respondents were asked: 'Did any of the following events happen as the result of seeing or hearing travel advertising, visiting a website about the destination, or receiving travel information about the destination?' Responses such as 'yes' was coded a value of 1 , and those responding 'no' or 'not sure' were coded values of 0 .

A possible limitation of this research relies on the degree to which people can accurately perceive or recall the influence that destination advertising on each travel related facet (Nisbett and Wilson, 1977). It is argued that the items to measure advertisement response were strong enough since tourists had to indicate if they were influenced or not by the promotional material they say or read (Dolnicar et al., 2011; Rossiter, 2011). The validity of this research was also influenced by an individual's capacity to recognize and remember 
tourism advertising, as well as if the advertising somehow influenced their travel behavior (Stienmetz et al., 2015).

Two analyses were performed in this study. Firstly, the mean visitor expenditures of those visitors influenced or not for each of the key facets were compared through independent sample $t$-tests. Secondly, the DAR model was evaluated using multivariate regression analysis, to assess the impact of facet based promotional material on visitor expenditures. The total trip expenditures at the destination was the dependent variable and the decisions to attend or purchase the facets of the trip were included as independent variables, i.e., Destination, Attractions, Restaurants, Events, Shopping, Accommodation. Multiple regression analysis was also performed with three groups of visitors regarding to the effectiveness of tourist destination advertising: those who were intermediated by traditional agencies; those who were intermediated by online travel agencies; and those who have planned and purchased the facets of the travel on their own (i.e., self-planners). Finally, the study provides discussions on how destinations can improve their competitiveness on tourist advertising by using new technologies.

\section{Results}

Table 2 shows the descriptive statistics of the sample from the 384 surveys collected. It was found that $52 \%$ of the respondents are female, and two-thirds (66\%) are between 25 and 44 years old. Approximately half of the sample (49.8\%) have a monthly household income of between $R \$ 1,500$ and $R \$ 3,699$ (1 Brazilian Real $R \$=$ US\$3.75 on 16 Nov 2018). Most respondents (54\%) live in a state far away from the destination (i.e., South, Southeast, Midwest of Brazil). Regarding the number of visits, $45.1 \%$ of respondents were in the destination for the first time, while $26.6 \%$ were for the second time. The most popular reasons for travel were vacations and weekend getaways, which accounted for $58.4 \%$ of the sample. Most tourists stayed between two and five days in the destination (65.4\%), and most started planning a trip between one to four weeks before traveling to the destination (41.1\%).

The Internet was the most common channel in which travelers were exposed to destination advertising (45.3\%), while TV/ radio ads came in second with $20.2 \%$ of the sample. When asked if they had any help to plan the trip, $50 \%$ of tourists said they planned their trips by themselves; $26 \%$ of the respondents used travel agencies to book their trip, and $24 \%$ were helped by online travel agencies to plan their visit to the destination. These findings confirm that travelers are increasingly using Internet to plan and book their trips without using travel agencies services.

\section{----- Insert Table 2 here -----}

An examination of destination advertising influence on the various decisions that comprise the trip planning process is shown in Table 3. A comparison between the conversion rates for five trip decisions (e.g., attractions, restaurants, events, shopping, and accommodations) to the 'true' destination choice conversion rate was performed. These six trip are significant items of overall trip expenditures (Park et al., 2013; Stienmetz et al., 2015). A conversion rate for each facet of the trip was calculated as the ratio of those that were exposed to destination advertising, and those that were influenced by the advertisements to visit featured destination facets such as attractions, restaurants, accommodations, events, and shopping (Stienmetz et al., 2015). Results of this analysis 
indicate that shopping and accommodations are the two facets that are most influenced by destination advertising. However, destination choice and events are the facets least influenced by destination advertising. The findings show that destination advertising influences each trip facet to varying degrees. Therefore, the DAR model appears to be an appropriate framework for measuring advertising response in destinations (Stienmetz et al., 2015).

\section{----- Insert Table 3 here -----}

Independent sample $t$-tests were then conducted to identify any differences in total destination spending between the groups of those visitors influenced for each trip facet (Table 4). The analysis was based on the travelers who were exposed to destination advertisements and visited the destination. In order to carry out the comparison test of means for independent samples, two groups of visitors were formed: (1) those who had their decisions influenced by promotional materials, and (2) those who did not feel influenced by promotional materials. The variables tested corresponded to those in which the visitors informed the estimate of their expenses in each facet (e.g., destination, attractions, restaurants, events, shopping, and accommodations).

Table 4 shows that in all cases promotional materials proved to be effective for the expenditure of visitors. Consistent with previous research (Stienmetz et al., 2015), the largest differences are found in 'Accommodations' and 'Attractions' facets. The former indicates that visitors who were influenced by promotional materials to visit featured accommodations spent $\mathrm{R} \$ 250.12$ on average more at the destination than those who did not feel influenced by advertisements $(t=6.454, p=0.000)$, while the latter indicates that the difference in spending consisted for attractions was $R \$ 203.45(t=6.213, p=0.000)$. Interestingly, no statistically significant difference $(\alpha>0.05)$ was found between the total travel expenditures of those that were influenced to visit a particular destination and those that were not $(t=1.510, p=0.112)$. These results are consistent with Stienmetz et al. (2015), where promotional materials are not necessarily relevant to spending choices when determining where to visit, but does influence spending on each specific facets of the trip.

\section{---- Insert Table 4 here -----}

A multivariate regression analysis was utilized to assess the impact of facet-level advertisement response on overall visitor expenditures (Table 5). The dependent variable was the total trip expenditures at the destination and the independent variables were the six trip facets: Destination, Attractions, Restaurants, Events, Shopping, Accommodation.

The resulting multiple regression analysis explains $77.5 \%$ of the variance in total visitor expenditure $\left(R^{2}=0.775\right.$, adjusted $\left.R^{2}=0.771, p=0.000\right)$. The results of the regression analysis indicate that trip characteristics have a significant impact on total visitor expenditure. A correlation analysis indicates that the 'Destination', 'Accommodations' and 'Restaurants' facets have high correlations with the average of total expenditure $(0.788$, 0.706 and 0.680 , respectively). While the 'Attractions' and 'Shopping' have moderate correlation ( 0.577 and 0.492 , respectively), and the facet 'Events' has low correlation (0.234). Findings also show that regression coefficients are statistically significant for advertising response for destination choice $(\beta=0.517, p=0.000)$, accommodations $(\beta=$ $0.298, p=0.000)$, and restaurants $(\beta=0.248, p=0.000)$. 
This study extended previous work on measuring the effectiveness of tourism advertising (Park et al., 2013; Stienmetz et al., 2015) by identifying three type of groups of visitors: a) intermediated by traditional agencies; b) intermediated by online travel agencies; c) those who planned their trip by themselves (self-planners). Tables 6, 7 and 8 show the results of the multiple regression analysis of these groups of visitors. The variance inflation factor (VIF) was examined to determine the level of collinearity, where a VIF value of 5.0 and higher indicates a potential collinearity problem. Results of VIF in the multiple regression analysis shown in Tables 5, 6, 7 and 8 were all below 5.0. Collinearity was not considered as an issue in these analyses.

Table 6 shows that the trip facets accounted for $63 \%$ of the variance explained for the total expenditure by the group of visitors who booked their trip through traditional agencies. The results show that 'Destination' $(\beta=0.439, p=0.000)$, and 'Accommodations' ( $\beta=0.454$, $p=0.000)$, were significant and directly explain the average of total expenses. They both had the highest correlation with the total expenses ( 0.651 and 0.646 respectively).

\section{----- Insert Table 6 here -----}

As for the group of visitors intermediated by online travel agencies (Table 7), the results of multiple regression model explain $76.5 \%$ of the variance in total visitor expenditure. Findings also show that regression coefficients of 'Destination' $(\beta=0.564, p=$ 0.000 ) and accommodations $(\beta=0.311, p=0.000)$ are statistically significant for advertising response. Destination and accommodation expenses are also the ones with the highest correlation with total expenditure ( 0.782 and 0.728 respectively).

\section{----- Insert Table 7 here -----}

Findings show that $83.7 \%$ of the total expenditure can be explained by the values of the traveling facets regarding to the self-planner visitors (Table 8 ). The results show that 'Destination' ( $\beta=0.564, p=0.000)$, 'Accommodations' $(\beta=0.173, p=0.000)$, and 'Restaurants' ( $\beta=0.218, p=0.000$ ) explained for the total expenditure by self-planners group. Spending on Destination, Restaurants, and Accommodations had a high correlation with total expenditure $(0.840,0.753$, and 0.698 respectively).

\section{----- Insert Table 8 here -----}

Looking at the figures of the three types of groups visitors (Tables 6,7 and 8), those intermediated by traditional agencies obtained the highest average of expenses ( $R \$ 2,377)$. In general, the 'Destination' facet was more representative for the average expenditure total. Comparing the results of the regression analysis of the three types of groups visitors, the self-planners got the highest variance explaining $83.7 \%$ in total visitor expenditure. This indicates that tourists are becoming empowered by assessing their options and being more autonomous in their decision-making. They make their travel planning experience more meaningful to them and reduce their dependency on travel experts for their planning tasks (Mendes-Filho et al., 2018). Findings also show that regression coefficients were statistically significant for destination and accommodations in all three type of groups. The findings corroborate research on the importance of the destination choice (Pratt et al., 2010) and 
accommodation (Park and Nicolau, 2015) to measure the effectiveness of destination marketing campaigns.

\section{Discussion and Conclusion}

Previous studies related to the evaluation of the effectiveness of destination promotional campaigns (Park et al., 2013; Park and Nicolau, 2015; Pratt et al., 2010; Qi et al., 2018; Stienmetz et al., 2015) have been used to identify important aspects which can assist DMOs in improving their promotional efforts. This research focused on evaluating the effectiveness of tourist destination advertising using the DAR Model (Stienmetz et al., 2015). Relevant results for the promotional management of tourism on visitor expenditures was found in six trip facets: destination, accommodations, attractions, restaurants, events, and shopping.

The results of the quantitative analyses indicate that trip facets have a significant impact on total visitor expenditure. This is consistent with previous research (Park et al., 2013; Stienmetz et al., 2015). Findings show that regression coefficients are statistically significant for advertising response for destination choice, accommodations, and restaurants.

This study contributes to the tourism literature performing a multiple regression analysis with three groups of visitors regarding to the effectiveness of tourist destination promotions: those who were intermediated by traditional agencies; those who were intermediated by online travel agencies; and those who have planned and purchased the facets of the travel on their own (i.e., self-planners). This division is an important contribution to the literature, because it describes different characteristics among these groups of visitors related to the six trip facets. For example, travelers of traditional agencies have shown to be the most profitable among the groups in spending in all the trips facets, and by being more aware of their exposure to tourist destination promotions in relation to the other two groups (i.e., online travel agencies and self-planners). The implementation of the tourist advertising of the destination should be based on the different characteristics listed by such groups. The most effective facet among all the groups on total visitor expenditure was 'Accommodations'. These results show that accommodation providers are working closer with travel agencies.

Also, new destinations without sufficient hotel rooms may want to promote Peer-to-Peer (P2P) accommodation economy (i.e., people providing accommodation directly to consumers, using digital platforms) as a stopgap solution. P2P accommodation is linked to increased domestic and Diaspora tourism, as well as engaging tourists in local activities and experiences in the destination (Bakker and Twining-Ward, 2018).

However, the 'Events' facet turned out to be non-effective for visitors to all groups. The tourist destination advertising should be increased for 'Events' facets. A suggestion would be to use "special events" as an attractor for competitive destinations in the smart tourism paradigm as one element of an effective destination strategy (Bustard et al., 2019). These events provide extraordinary experiences at scale and are critical to destination image and marketing efforts (Bustard et al., 2019). To co-create opportunities around events at destinations are reliant on the exchange of touristic resources, facilitated by technologies integrating into the many stages of what is coming to be known as the smart experience (Gretzel et al., 2015). 
The number of visitors that carried out their own planning is considerably higher (50\%) than the number of visitors presented in the other groups (travel agencies $=26 \%$ and online travel agencies $=24 \%)$. Also, self-planners got the highest variance explaining $\left(R^{2}=\right.$ 0.837) in total visitor expenditure, compared to the regression analysis results of the other two groups (i.e., travel agencies and online travel agencies). The travelers were mostly exposed to information and destination advertising from the Internet (45.3\%), while $20.2 \%$ were exposed to TV/radio ads and $19.9 \%$ to newspaper/magazine ads.

Businesses were more in control of the conversation using magazines and TV channels with their consumers prior to the advent of online booking and the social media (Salem and Twining-Ward, 2018). Destinations are constantly evolving and print publications struggle to keep pace with this change. Consumers are now looking for real-time tourism content such as User-Generated Content (UGC), i.e., any text or visual piece of content created by an individual user that they share with their networks, publicly and/or privately on the Internet (Salem and Twining-Ward, 2018). For example, TripAdvisor have grown to 660 million in 2018, and these reviews are followed by higher tourism demand and increased nights at the destination (Oxford Economics \& TripAdvisor Insights, 2018).

The self-planners are planning their trips using UGC without going to travel agencies anymore. Previous studies suggests that the informational power held by travel agencies may shift as tourists turn more to online communities for travel advice (Casaló et al., 2011). The Internet and other technologies have become increasingly useful and even essential to plan trips, supporting key activities such as destination choice, and deciding on what to eat and where to shop (Xiang et al., 2015).

The competitiveness of a destination is relying more and more on the ability to include more technologies (Shoval and Birenboim, 2018). Technology has been revolutionizing destination marketing as they combine a radically improved and rapidly evolving computing systems (e.g., cloud computing and Big Data) with better communications (e.g., Internet) in order to satisfy the tourism industry (Buhalis, 2000). This should be a concern of DMOs to promote more destinations in the digital environment. Travelers will get information easier about destinations, especially for those visitors intermediated by online travel agencies, and self-planners, who tend to use more Internet to plan their trip. With the growing importance of social media, destinations need to implement news feeds and integrate their social media channels in the website (Mistilis et al., 2014). The ability to enhance travel experiences will rely on the capacity to find ways to communicate and promote the right experience to the right tourist in the right destination (Tussyadiah, 2016).

Since the use of technologies continue to gain in popularity among travelers, what technologies can be used to improve the effectiveness of tourist advertising and competitiveness of destinations? Destinations and DMOs need to improve their competitiveness on tourist promotion and advertising campaigns by using tools that rely on new technologies such as cloud computing, Internet of Things (IoT), Big Data, Virtual Reality (VR), and drones (Buhalis and Leung, 2018; Shoval and Birenboim, 2018; Tussyadiah et al., 2018; Wang et al., 2012).

Technologies such as cloud computing and loT have been used to obtain data from tourists with apps (Boes et al., 2016). They can produce useful information relating to tourism attractions and tourists' behaviour to promote better the destinations (Thomaz et al., 2017; Wang et al., 2013). Also, a real-time monitoring from Big Data enables DMOs to 
analyse the information dynamically, and helps to promote destinations and events (Buhalis and Leung, 2018; Neuhofer et al., 2015).

Virtual tours are used to provide enjoyment of travel experiences by applying threedimensional VR software (Li et al., 2017), supporting destinations improve their advertising campaigns and promotional efforts. VR applications can really increase the transparency of the tourism product (Mistilis et al., 2014). Tourism businesses are using drones and aerial filming to promote destinations and attract customers (Flynn, 2016; Skyseevideo, 2017). Visitors can choose the content they will be exposed during their travels to destinations based on their interest and preferences (Shoval and Birenboim, 2018).

Destinations need to invest more resources in technologies to customize their product which will allow them to generate a personalized experience to what they perceive as desired travelers, and this will help to attract more tourists (Shoval and Birenboim, 2018). For instance, listings on digital platforms need to be actively promoted in tourist destinations where very little tourism demand exists, and this can be done in partnership with DMOs (Bakker and Twining-Ward, 2018). The democratization of digital media has lowered the costs to tourism advertising, providing new opportunities for low-income countries (e.g., Brazil) and small tourism businesses to connect with online travelers, and allowing destinations to become more sustainable and competitive (Herrero et al., 2015; Salem and Twining-Ward, 2018). Thus, destinations no longer need multimillion dollar marketing budgets to be successful using Internet and UGC in their advertising campaigns to both drive revenue and reduce the costs of content (Mistilis et al., 2014; Salem and Twining-Ward, 2018). Knowledge of the digital platforms coupled with the right strategies will help destinations and businesses become more competitive and use their marketing development resources more effectively (Salem and Twining-Ward, 2018).

At the same time, destinations could create marketing messages based on the travelers' experience instead of focusing the tourism marketing efforts on their physical attributes (Ketter, 2018). DMOs could use at the most memorable experiences that tourists underwent in the destinations and integrate them into the brand's promise, and then attract tourists and visitors more effectively. Having said that, experience marketing campaigns represent a segment that focuses on the modern tourists who are interested in much more than the traditional tourism product (Ketter, 2018). The destinations of the future will then need to engage consumers in the delivery and cocreation of value (Mistilis et al., 2014).

This study focused on Brazilian tourists which is culturally different to European and Asian travelers. The findings may also differ for other travelers from developed countries who have more money to spend on destinations. Future research can extend this study by examining other variables that complement the DAR model and evaluate better the effectiveness of tourist destination advertising. Qualitative research on this subject is recommended, in order to identify different groups of tourist consumers, their characteristics, and the possibilities to include such groups in models such as DAR. The study was also cross-sectional in nature. A longitudinal study may provide further insight into the trip facets related to tourist destination advertising.

\section{References}

Agência Brasil (2017) Brasil tem recorde de 6,6 milhões de turistas estrangeiros em 2016. Available at: http://agenciabrasil.ebc.com.br/geral/noticia/2017-01/brasil-tem-recorde- 
de-66-milhoes-de-turistas-estrangeiros-em-2016 (accessed 25 October 2018).

Bakker MHE and Twining-Ward LD (2018) Tourism and the Sharing Economy: Policy \&

Potential of Sustainable Peer-to-Peer Accommodation. Washington: World Bank Group. Available at:

http://documents.worldbank.org/curated/en/161471537537641836/Tourism-and-theSharing-Economy-Policy-Potential-of-Sustainable-Peer-to-Peer-Accommodation.

Boes K, Buhalis D and Inversini A (2016) Smart tourism destinations: ecosystems for tourism destination competitiveness. International Journal of Tourism Cities 2(2): 108-124.

Buhalis D (2000) Tourism and Information Technologies: Past, Present and Future. Tourism Recreation Research 25(1): 41-58.

Buhalis D and Leung R (2018) Smart hospitality-Interconnectivity and interoperability towards an ecosystem. International Journal of Hospitality Management 71. Pergamon: 41-50.

Bustard JRT, Bolan P, Devine A, et al. (2019) The emerging smart event experience: an interpretative phenomenological analysis. Tourism Review 74(1): 116-128.

Butterfield DW, Kubursi AA and Deal KR (1998) Measuring the returns of tourism advertising. Journal of Travel Research 37(1): 12-20.

Cai LA (1998) Effects of Destination Advertising on Financial Returns - A Comparative Analysis of Two Inquiring Methods. Journal of Hospitality Financial Management 6(1): 61-73.

Casaló L V., Flavián C and Guinalíu M (2011) Understanding the intention to follow the advice obtained in an online travel community. Computers in Human Behavior 27(2): 622-633.

Choe Y, Stienmetz JL and Fesenmaier DR (2017) Measuring Destination Marketing:

Comparing Four Models of Advertising Conversion. Journal of Travel Research 56(2): 143-157.

Dolnicar S, Grün B and Leisch F (2011) Quick, Simple and Reliable: Forced Binary Survey Questions. International Journal of Market Research 53(2): 231-252.

Flynn S (2016) How Drones Are Changing Tourism Marketing. Available at:

https://skytango.com/how-drones-are-changing-tourism-marketing/ (accessed 16 October 2018).

Gretzel U, Sigala M, Xiang Z, et al. (2015) Smart tourism: foundations and developments. Electronic Markets 25(3): 179-188.

Herrero A, San Martín H and Hernández JM (2015) How online search behavior is influenced by user-generated content on review websites and hotel interactive websites. International Journal of Contemporary Hospitality Management 27(7): 1573-1597.

Ketter E (2018) It's all about you: destination marketing campaigns in the experience economy era. Tourism Review 73(3): 331-343.

Kim D, Hwang Y and Fesenmaier DR (2005) Modeling Tourism Advertising Effectiveness. Journal of Travel Research 44(1): 42-49.

Klenosky DB and Gitelson RE (1997) Characteristics of Effective Tourism Promotion Slogans. Annals of Tourism Research 24(1): 235-238.

Li Y, Hu C, Huang C, et al. (2017) The concept of smart tourism in the context of tourism information services. Tourism Management 58. Pergamon: 293-300.

McLemore C and Mitchell N (2001) An Internet Conversion Study of www.arkansas.com - A State Tourism Website. Journal of Vacation Marketing 7(3): 268-274.

McWilliams EG and Crompton JL (1997) An expanded framework for measuring the effectiveness of destination advertising. Tourism Management 18(3): 127-137. 
Mendes-Filho L, Mills AM, Tan FB, et al. (2018) Empowering the traveler: an examination of the impact of user-generated content on travel planning. Journal of Travel and Tourism Marketing 35(4): 425-436.

Ministério do Turismo (2016) Mais de 6 milhões de turistas estrangeiros visitaram o Brasil em 2015. Available at: http://www.turismo.gov.br/últimas-notícias/6131-mais-de-6milhões-de-estrangeiros-visitaram-o-brasil-em-2015.html (accessed 25 October 2018).

Mistilis N, Buhalis D and Gretzel U (2014) Future eDestination Marketing: Perspective of an Australian Tourism Stakeholder Network. Journal of Travel Research 53(6): 778-790.

Neuhofer B, Buhalis D and Ladkin A (2015) Smart technologies for personalized experiences: A case study in the hospitality domain. Electronic Markets 25(3): 243-254.

Nisbett RE and Wilson TD (1977) Telling more than we can know: Verbal reports on mental processes. Psychological Review 84: 231-259.

Oxford Economics \& TripAdvisor Insights (2018) Sizing Worldwide Tourism Spending (or "GTP") \& TripAdvisor's Economic Impact. Available at: https://www.tripadvisor.com/TripAdvisorInsights/wpcontent/uploads/2018/05/Worldwide-Tourism-Economics-2017.pdf (accessed 12 February 2019).

Park S and Fesenmaier DR (2012) Non-response Bias in Internet-Based Advertising Conversion Studies. International Journal of Culture, Tourism and Hospitality Research 6(4): 340-355.

Park S and Nicolau JL (2015) Differentiated effect of advertising: Joint vs. separate consumption. Tourism Management 47: 107-114.

Park S, Nicolau JL and Fesenmaier DR (2013) Assessing advertising in a hierarchical decision model. Annals of Tourism Research 40(1): 260-282.

Pratt S, McCabe S, Cortes-Jimenez I, et al. (2010) Measuring the Effectiveness of Destination Marketing Campaings: Comparative Analysis of Conversion Studies. Journal of Travel Research 49(2): 179-190.

Qi R, Cárdenas DA, Mou X, et al. (2018) The strategic value of advertising expenditures in the tourism and hospitality industry. Tourism Economics 24(7): 872-888.

Rossiter JR (2011) Marketing Measurement Revolution: The C-OAR-SE Method and Why It Must Replace Psychometrics. European Journal of Marketing 45(1/2): 1561-1588.

Salem TM and Twining-Ward LD (2018) The Voice of Travelers: Leveraging User-Generated Content for Tourism Development 2018. Washington: World Bank Group. Available at: http://documents.worldbank.org/curated/en/656581537536830430/The-Voice-ofTravelers-Leveraging-User-Generated-Content-for-Tourism-Development-2018.

Sergipe (2015) Setesp - Secretaria de Estado do Turismo e Esporte. Relatório de atividades 2015. Aracaju.

Shoval N and Birenboim A (2018) Customization and augmentation of experiences through mobile technologies. Tourism Economics: 1-9. DOI: 10.1177/1354816618806428.

Siegel W and Ziff-Levine W (1990) Evaluating tourism advertising campaigns: conversion vs advertising tracking studies. Journal of Travel Research 28(3): 51-55.

Skyseevideo (2017) How Drones are Pioneering a New Age of Tourism. Available at: ttps://skyseevideo.com/drones-pioneering-new-age-tourism/ (accessed 16 October 2018).

Stergiou D and Airey D (2003) Inquiry Conversion and Tourism Website Effectiveness: Assumptions, Problems and Potential. Tourism and Hospitality Research 4(4): 355-366. Stienmetz J, Maxcy J and Fesenmaier DR (2015) Evaluating Destination Advertising. Journal 
of Travel Research 54(1): 22-35.

Straub D, Gefen D and Gefen D (2004) Validation Guidelines for IS Positivist Research. Communications of the Association for Information Systems 13(24): 380-427.

Thomaz GM, Biz AA, Bettoni EM, et al. (2017) Content mining framework in social media: A FIFA world cup 2014 case analysis. Information and Management 54(6): 786-801.

Tussyadiah IP (2016) The Influence of Innovativeness on On-Site Smartphone Use Among American Travelers: Implications for Context-Based Push Marketing. Journal of Travel \& Tourism Marketing 33(6). Routledge: 806-823.

Tussyadiah IP, Jung TH and tom Dieck MC (2018) Embodiment of Wearable Augmented Reality Technology in Tourism Experiences. Journal of Travel Research 57(5): 597-611.

Uysal $\mathrm{M}$ and Crompton J (1984) Determinants of demand for international tourist flows to Turkey. Tourism Management 5(4): 288-297.

Volchek K, Liu A, Song H, et al. (2018) Forecasting tourist arrivals at attractions: Search engine empowered methodologies. Tourism Economics: 1-23. DOI: $10.1177 / 1354816618811558$.

Wang D, Park S and Fesenmaier D (2012) The Role of Smartphones in Mediating the Touristic Experience. Journal of Travel Research 51(4): 371-387.

Wang D, Li X and Li Y (2013) China's smart destination initiative: a taste of the servicedominant logic. Journal of Destination Marketing \& Management 2(2): 59-61.

Wicks BE and Schuett MA (1991) Examining the Role of Tourism Promotion through the Use of Brochures. Tourism Management 12(4): 301-312.

Xiang Z, Wang D, O'Leary JT, et al. (2015) Adapting to the Internet: Trends in Travelers' Use of the Web for Trip Planning. Journal of Travel Research 54(4): 511-527. 
Table 1. Summary Statistics for the Attitude Toward Advertisements Scale.

\begin{tabular}{lllllllll}
\hline Item & $\mathrm{M}$ & $\mathrm{SD}$ & 1 & 2 & 3 & 4 & 5 & 6 \\
\hline 1. Attractive & 3.92 & 1.093 & & & & & & \\
2. Features & 3.95 & 1.087 & 0.925 & & & & & \\
3. Trust & 3.63 & 1.186 & 0.766 & 0.783 & & & & \\
4. Help & 3.66 & 1.208 & 0.769 & 0.751 & 0.829 & & & \\
5. Place & 3.68 & 1.219 & 0.758 & 0.767 & 0.802 & 0.939 & & \\
6. Knowledge & 3.59 & 1.263 & 0.724 & 0.715 & 0.793 & 0.802 & 0.796 & \\
7. Plan & 3.26 & 1.285 & 0.638 & 0.673 & 0.685 & 0.713 & 0.766 & 0.711 \\
\hline
\end{tabular}

Note: All correlations are significant at $\mathrm{p}<0.001$. Attractive $=$ the travel advertisements about the destination were attractive; Features = showing interesting and unique features of the destination; Trust $=$ accurate and trustworthy; Help = helping you think about what it might be like to visit the destination; Place = helping you think about different places to visit in the destination; Knowledge = improving your knowledge about the destination; Plan = helpful in planning your trip to/through the destination (Stienmetz et al., 2015)

Table 2. Sample characteristics.

\begin{tabular}{|c|c|c|c|}
\hline Variable & $\%$ & Variable & $\%$ \\
\hline Gender & & Trip type & \\
\hline Male & 47.9 & Vacation & 31.8 \\
\hline Female & 52.1 & Weekend getaway & 26.6 \\
\hline Age & & Visit friends of relatives & 16.4 \\
\hline $18-24$ & 20.6 & Event & 11.1 \\
\hline $25-34$ & 44 & Business & 8.9 \\
\hline $35-44$ & 21.9 & Others & 5.2 \\
\hline $45-54$ & 8.6 & Trip length & \\
\hline $55-64$ & 4.4 & Day Trip & 11.2 \\
\hline$\geq 65$ & 0.5 & 1 night & 4.7 \\
\hline Household income (R\$ - monthly) & & 2 nights & 29.7 \\
\hline$<880$ & 2.1 & 3-5 nights & 35.7 \\
\hline $880-1499$ & 5.7 & $6-10$ nights & 10.7 \\
\hline $1500-2699$ & 21.4 & $\geq 11$ nights & 8.1 \\
\hline $2700-3699$ & 28.4 & Time of planning & \\
\hline $3700-5399$ & 13.8 & Never planned trip & 2.6 \\
\hline $5400-7399$ & 10.4 & Day of trip & 0.8 \\
\hline $7400-9399$ & 12.2 & $1-6$ days before trip & 15.1 \\
\hline$\geq 9400$ & 6 & 1-4 weeks before trip & 41.1 \\
\hline Distance from destination & & $5-8$ weeks before trip & 23.7 \\
\hline Adjacent destination & 23.7 & $>2$ months before trip & 16.7 \\
\hline Other state of Brazilian Northeast & 19.3 & Ad channel exposure & \\
\hline North & 3.1 & Internet ads & 45.3 \\
\hline South & 6.3 & TV/Radio ads & 20.2 \\
\hline Southeast & 34.9 & Newspaper/Magazine ads & 19.9 \\
\hline Midwest & 12.8 & Other ads & 14.6 \\
\hline Total visits to the destination & & Plan of trip & \\
\hline 1 & 45.1 & Traditional agency & 26 \\
\hline 2 & 26.6 & Online travel agency & 24 \\
\hline
\end{tabular}




\begin{tabular}{llll}
\hline $3-5$ & 13 & Self-planner & 50 \\
$6-10$ & 3.1 & & \\
$>11$ & 12.2 & & \\
\hline
\end{tabular}

Table 3. Ads' Influence on Visitors' Individual Trip Decision Facets.

\begin{tabular}{ll}
\hline Trip decision & Conversion Rates (\%) \\
\hline Visiting a featured store or shop & 66.9 \\
Staying at featured accommodations & 61.7 \\
Visiting a featured attraction & 60.7 \\
Visiting a featured restaurant & 42.4 \\
Destination choice & 37.5 \\
Visiting a featured event & 34.9 \\
\hline
\end{tabular}

Table 4. Total Trip Expenditure Based on Facet-Based Advertisement Response.

\begin{tabular}{lllllll}
\hline Trip facet & $\begin{array}{l}\text { Ad } \\
\text { influenced } \\
\text { facet } \\
\text { decision }\end{array}$ & $\begin{array}{l}\text { No Influence } \\
\text { on facet } \\
\text { decision }\end{array}$ & $\begin{array}{l}\text { Mean } \\
\text { difference }\end{array}$ & $t$ & $D f$ & Significance \\
\hline Destination & $\mathrm{R} \$ 672.56$ & $\mathrm{R} \$ 600.20$ & $\mathrm{R} \$ 72.36$ & 1.510 & 382 & 0.112 \\
Accommodations & $\mathrm{R} \$ 533.33$ & $\mathrm{R} \$ 283.21$ & $\mathrm{R} \$ 250.12$ & 6.454 & 381 & 0.000 \\
Attractions & $\mathrm{R} \$ 394.84$ & $\mathrm{R} \$ 191.39$ & $\mathrm{R} \$ 203.45$ & 6.213 & 382 & 0.000 \\
Events & $\mathrm{R} \$ 151.49$ & $\mathrm{R} \$ 6.40$ & $\mathrm{R} \$ 145.09$ & 16.872 & 382 & 0.000 \\
Restaurants & $\mathrm{R} \$ 352.76$ & $\mathrm{R} \$ 280.54$ & $\mathrm{R} \$ 72.22$ & 3.181 & 382 & 0.002 \\
Shopping & $\mathrm{R} \$ 258.36$ & $\mathrm{R} \$ 153.22$ & $\mathrm{R} \$ 105.14$ & 5.217 & 382 & 0.000 \\
\hline
\end{tabular}

Table 5. Results of Multiple Regression Analysis.

\begin{tabular}{|c|c|c|c|c|c|c|}
\hline Item & Mean & $1(r)$ & Sig & $\beta$ & Tolerance & VIF \\
\hline 1. Total expenditure & $\mathrm{R} \$ 1,792$ & & & & & \\
\hline $\begin{array}{l}\text { 2. Destination } \\
\text { expenses }\end{array}$ & $\mathrm{R} \$ 438$ & 0.788 & 0.000 & 0.517 & 0.646 & 1.547 \\
\hline $\begin{array}{l}\text { 3. Accommodation } \\
\text { expenses }\end{array}$ & $\mathrm{R} \$ 314$ & 0.706 & 0.000 & 0.298 & 0.508 & 1.969 \\
\hline $\begin{array}{l}\text { 4. Attractions } \\
\text { expenses }\end{array}$ & $\mathrm{R} \$ 311$ & 0.577 & 0.886 & 0.005 & 0.451 & 2.218 \\
\hline 5. Events expenses & $\mathrm{R} \$ 57$ & 0.234 & 0.368 & 0.023 & 0.883 & 1.133 \\
\hline $\begin{array}{l}\text { 6. Restaurants } \\
\text { expenses }\end{array}$ & $\mathrm{R} \$ 223$ & 0.680 & 0.000 & 0.248 & 0.365 & 2.739 \\
\hline $\begin{array}{l}\text { 7. Shopping } \\
\text { expenses }\end{array}$ & $\mathrm{R} \$ 221$ & 0.492 & 0.203 & -0.044 & 0.498 & 2.009 \\
\hline
\end{tabular}

$\mathrm{R}^{2}=0.775, \mathrm{R}^{2}$ adjusted $=0.771$, ANOVA (Sig) $=0.000$ a

Note: 1 ( $r$ ) - Pearson's correlation between trip facets and total expenditure; Sig - significance; $\beta$ - Beta standardized; VIF - Variance Inflation Factor; R - coefficient of determination. 
Table 6. Results of Multiple Regression Analysis (visitors intermediated by traditional agencies).

\begin{tabular}{|c|c|c|c|c|c|c|}
\hline Item & Mean & $1(r)$ & Sig & $\beta$ & Tolerance & VIF \\
\hline 1. Total expenditure & $\mathrm{R} \$ 2,377$ & & & & & \\
\hline $\begin{array}{l}\text { 2. Destination } \\
\text { expenses }\end{array}$ & $\mathrm{R} \$ 946$ & 0.651 & 0.000 & 0.439 & 0.661 & 1.514 \\
\hline $\begin{array}{l}\text { 3. Accommodation } \\
\text { expenses }\end{array}$ & $\mathrm{R} \$ 586$ & 0.646 & 0.000 & 0.454 & 0.514 & 1.946 \\
\hline $\begin{array}{l}\text { 4. Attractions } \\
\text { expenses }\end{array}$ & $\mathrm{R} \$ 475$ & 0.452 & 0.211 & 0.121 & 0.434 & 2.304 \\
\hline 5. Events expenses & $\mathrm{R} \$ 40$ & 0.259 & 0.846 & -0.013 & 0.861 & 1.161 \\
\hline $\begin{array}{l}\text { 6. Restaurants } \\
\text { expenses }\end{array}$ & $\mathrm{R} \$ 409$ & 0.501 & 0.702 & 0.129 & 0.378 & 2.643 \\
\hline $\begin{array}{l}\text { 7. Shopping } \\
\text { expenses }\end{array}$ & $\mathrm{R} \$ 271$ & 0.319 & 0.518 & -0.063 & 0.423 & 2.366 \\
\hline
\end{tabular}

Table 7. Results of Multiple Regression Analysis (visitors intermediated by online travel agencies).

\begin{tabular}{|c|c|c|c|c|c|c|}
\hline Item & Mean & $1(r)$ & Sig & $\beta$ & Tolerance & VIF \\
\hline 1. Total expenditure & $\mathrm{R} \$ 1,521$ & & & & & \\
\hline $\begin{array}{l}\text { 2. Destination } \\
\text { expenses }\end{array}$ & $\mathrm{R} \$ 486$ & 0.782 & 0.000 & 0.564 & 0.629 & 1.591 \\
\hline $\begin{array}{l}\text { 3. Accommodation } \\
\text { expenses }\end{array}$ & $\mathrm{R} \$ 409$ & 0.728 & 0.000 & 0.311 & 0.376 & 2.660 \\
\hline $\begin{array}{l}\text { 4. Attractions } \\
\text { expenses }\end{array}$ & $\mathrm{R} \$ 202$ & 0.536 & 0.553 & -0.063 & 0.243 & 4.109 \\
\hline 5. Events expenses & $\mathrm{R} \$ 71$ & 0.352 & 0.658 & 0.027 & 0.764 & 1.309 \\
\hline $\begin{array}{l}\text { 6. Restaurants } \\
\text { expenses }\end{array}$ & $\mathrm{R} \$ 219$ & 0.578 & 0.094 & 0.198 & 0.200 & 4.993 \\
\hline $\begin{array}{l}\text { 7. Shopping } \\
\text { expenses }\end{array}$ & $\mathrm{R} \$ 176$ & 0.528 & 0.617 & 0.037 & 0.513 & 1.951 \\
\hline
\end{tabular}

Table 8. Results of Multiple Regression Analysis (self-planners) 


\begin{tabular}{|c|c|c|c|c|c|c|}
\hline Item & Mean & $1(r)$ & Sig & $\beta$ & Tolerance & VIF \\
\hline 1. Total expenditure & $\mathrm{R} \$ 1,617$ & & & & & \\
\hline $\begin{array}{l}\text { 2. Destination } \\
\text { expenses }\end{array}$ & $\mathrm{R} \$ 528$ & 0.840 & 0.000 & 0.564 & 0,498 & 2.008 \\
\hline $\begin{array}{l}\text { 3. Accommodation } \\
\text { expenses }\end{array}$ & $\mathrm{R} \$ 375$ & 0.698 & 0.000 & 0.173 & 0.390 & 2.561 \\
\hline $\begin{array}{l}\text { 4. Attractions } \\
\text { expenses }\end{array}$ & $\mathrm{R} \$ 285$ & 0.679 & 0.005 & 0.151 & 0.311 & 3.217 \\
\hline 5. Events expenses & $\mathrm{R} \$ 58$ & 0.278 & 0.041 & 0.070 & 0.764 & 1.309 \\
\hline $\begin{array}{l}\text { 6. Restaurants } \\
\text { expenses }\end{array}$ & $\mathrm{R} \$ 304$ & 0.753 & 0.000 & 0.218 & 0.279 & 3.579 \\
\hline $\begin{array}{l}\text { 7. Shopping } \\
\text { expenses }\end{array}$ & $\mathrm{R} \$ 221$ & 0.480 & 0.025 & -0.092 & 0.534 & 1.871 \\
\hline
\end{tabular}

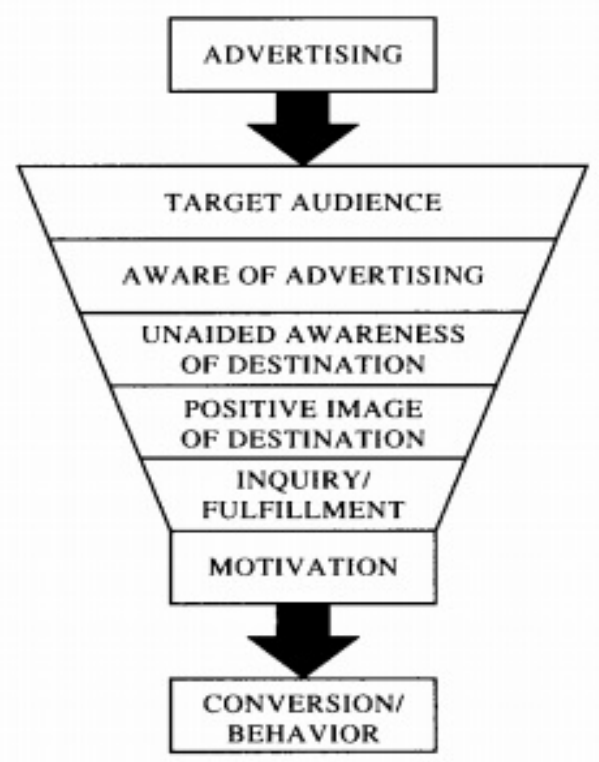

Figure 1. Conversion Model

Source: Seigel and Ziff-Levine, 1990 


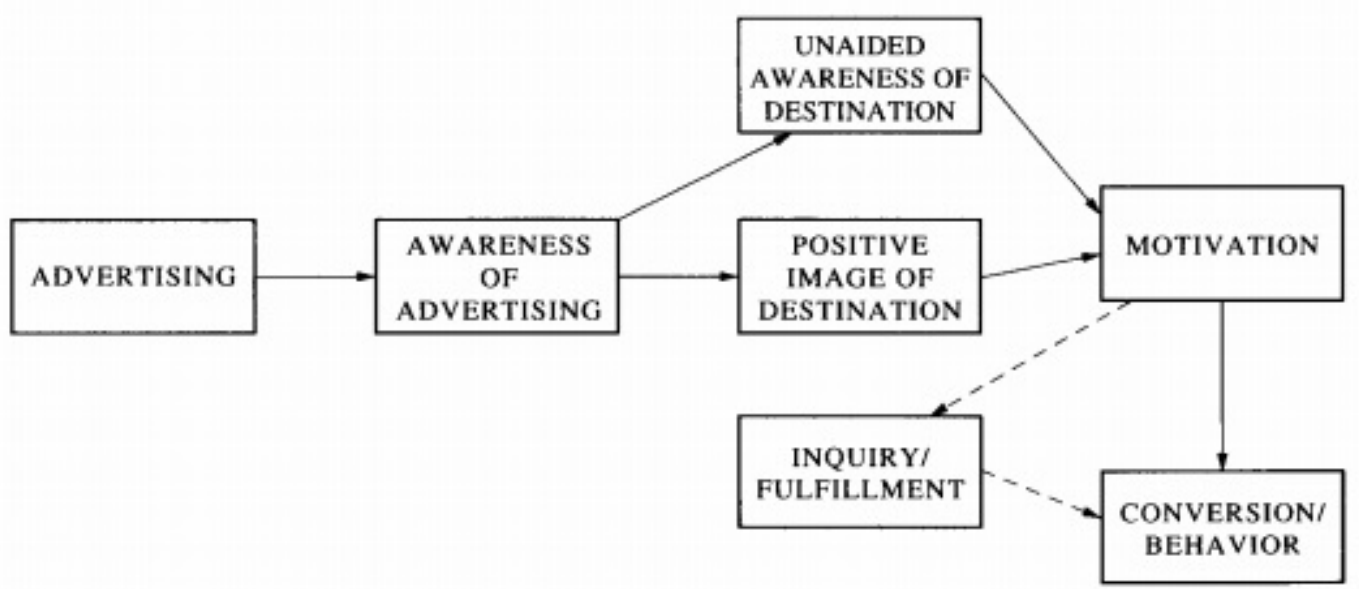

Figure 2. Adversiting tracking model

Source: Seigel and Ziff-Levine, 1990
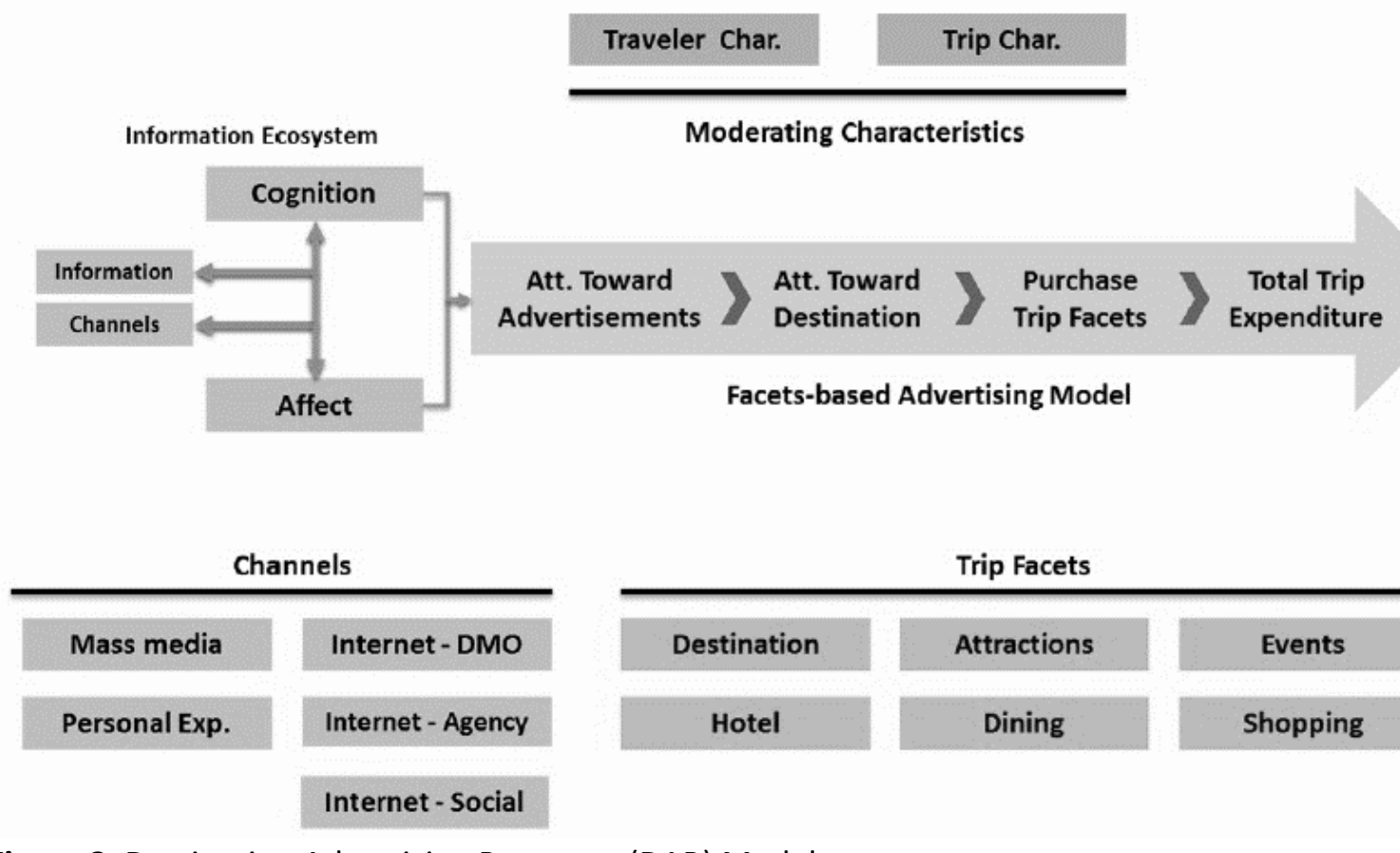

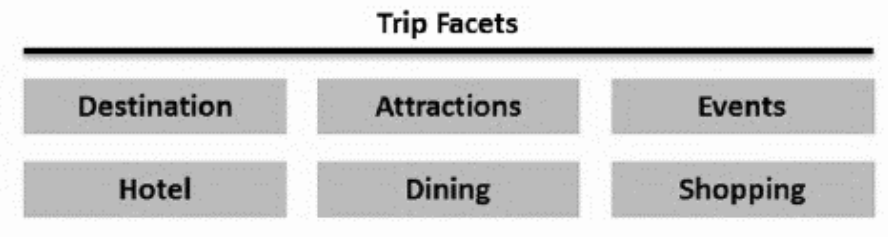

Figure 3. Destination Advertising Response (DAR) Model

Source: Stienmetz, Maxcy and Fesenmaier (2015) 